\title{
前立腺癌の組織学的検討：生検時捛よび剖検時の比較
}

\author{
千葉大学医学部泌尿器科学教室（主任：島崎 淳教授) \\ 安藤研布施 秀樹島崎 淳 \\ 旭中央病院泌尿器科（部長：村上信乃） \\ 村上信 乃 \\ 帝京大学医学部付属市原病院病理部（主任：長尾孝一教授） \\ 松㟢理
}

\section{COMIPARISON OF GRADE OF PROSTATE CANCER BETWEEN PRETREATMENT AND AUTOPSY}

\author{
Ken Ando, Hideki Fuse and Jun Shimazaki \\ Department of Urology, School of Medicine, Chiba University, Chiba \\ (Director: Prof. J. Shimazaki) \\ Shino Murakami \\ Department of Urology, Asahi General Hospital \\ (Director: S. Murakami) \\ Osamu Matsuzaki
}

Department of Surgical Pathology, Ichihara Hospital, University of Teikyo, School of Medicine, Ichihara

(Director: Prof. K. Nagao)

In 37 cases of prostate cancer treated by endocrine therapy, grade was compared between the specimen obtained at the start of treatment and that at autopsy.

Nine cases of 23 of moderately differentiated cancers as the start of the treatment progressed to poorly differentiated cancers and the other showed no change during the courses. There were similar grades during whole courses in cases showing poorly differentiated cancers at the start of treatment.

Seven cases of 16 of poorly differentiated cancers at the start showed unresponsiveness to endocrine therapy.

At autopsy, the same grade was observed between the prostate and the sites of metastases.

\begin{abstract}
要旨：前立腺癌は経過中に組織学的分化度を変化し，再燃後には，低分化傾向がみられることを既に報 告した（日泌尿会誌，74：989，1983）。今回さらに症例を追加し，生検時と剖検時の病理組織像の比較 を行なった。用いた37例は，全例癌死であり，いずれも内分泌療法が施行された。生検剖検間に取扱い 規約による分化度の変化をみたものが 9 例，不変のものは28例であり，前者はすべて中分化型が低分化 型となったもので，後者は中分化型12例，低分化型16例であった．低分化型で分化度の不変のものに内 分泌療法無効例が多かった。生検剖検間で取扱い規約により不変とされた28例でも Gleason score でみ ると、その40\%は剖検時 scoreが大となっていた。したがって内分泌療法後に再燃したものは, 治療前に 比べて，低分化傾向になるとみなせた．剖検時，転移部位の分化度は，多くは，原発巣と同じ分化度で あった。
\end{abstract}

\section{緒言}

Huggins ら ${ }^{1} に よ り$ 提唱された前立腺癌に対する内 分泌療法は治療開始時には，有効性が高く，治療の主
体をなしてきたが, 数年のらちに過半数が内分泌療法 に対する反応性を失ない再燃する。再燃例の予後はよ くなく, 前立腺癌の治療上, その対策は重要な問題と 
なる，再燃の機序は，いろいろ討議されているが，ま だ不明である ${ }^{2}$. 既に当教室より ${ }^{3)}$ 内分泌潦法後再燃す るに従い，組織像の変化することを報告したが，今回 さらに症例を加えて内分泌療法に対する反応性の変化 と組織像との関係を検討した。

\section{対象および方法}

1963年より1984年までに千葉大学新よび旭中央病院 泌尿器科に扣いて剖検した前立腺癌37例を対象とし た。治療開始時，生検組織材料を兄たが，これは針生 検35例，前立腺全摘除術招よび被膜下摘除術は，それ ぞれ 1 例であった。

初回治療として内分泌療法4)（去勢抒よび直後より ジェチルスティルベストロール2燐酸250 500mg 1 カ月投与, 以後へキセストロール $30 \mathrm{mg} /$ 日委たはエチ ニルエストラジオール1 3mg/日投与）を施行したも のが27例，放射線療法 7 例，下垂体照射 2 例沶よび前 立腺全摘除術 1 例である. 初回放射線療法の全例と前 立腺全摘除術 1 例はすべて再発し, その後, 内分泌療 法を実施された。初回ないし追加内分泌㞠法の治療効 果の不十分なるの扣よび内分泌療法後, 再燃した例に は化学療法を追加した。

内分泌療法等により制癌後, 原発巣ないし転移巣の 新たな発生や増悪したものを，それぞれ局所または全 身再燃とした ${ }^{5)}$.これの診断にはレ線，骨シンチグラ フィーおよび前立腺超音波断層法を用いた。酸性フォ スファターゼの上昇のみは，再燃と判定しなかった。

病理組織分化度 (以下 grade) は Gleason system ${ }^{6)}$ 扔よび前立腺癌取扱い規約 ${ }^{71}$ に従った. Gleason systemは, pattern 1，2を高分化型，3を中分化型，4， 5を低分化型としたが，これは，ほぼ取扱い規約の高， 中拀よび低分化型と同じであったため区別しなかっ た。また primary pattern と secondary pattern の Gleason 評点の和を score とした。原発巣の生検時と 剖検時の grade (取扱い規約)を比較し, gradeの变化 したものを変化群, 変わらないものを不変群とした。

\section{結 果}

1）生検時および剖検時の grade：生検時の grade は，中分化型21例(57\%)，低分化型16例(43\%)であっ た. scoreでみると，8 が大部分を占め，以下 6 抢よび 9，ついで 5 㧊よび10となっており，悪性度の大であ る score 8 以上が $90 \%$ 以上を占めた (Table 1).

生検と剖検の比較では, 不変群が潘ぼ $3 / 4$ を占め, 他 は変化群であった。変化群は, 全例, 中分化型が低分 化型となったものであった（Fig. 1)。な招, 前立腺全
Table 1. 生検時の組織所見

\begin{tabular}{|c|c|}
\hline 生検時 grade* & 例 数 \\
\hline $\begin{array}{l}\text { 中分 化 型 } \\
\text { 低 分 化 型 }\end{array}$ & $\begin{array}{l}21(57) \\
16(43)\end{array}$ \\
\hline 計 & 37 \\
\hline Gleason score & 例 数 \\
\hline 5 & $1(3)$ \\
\hline 6 & $2(5)$ \\
\hline 8 & $31(84)$ \\
\hline 9 & $2(5)$ \\
\hline 10 & $1(3)$ \\
\hline 計 & 37 \\
\hline
\end{tabular}

Fig. 1. 症例 K.A.

a. 中分化型（前立腺，生検），b．低分化型（前立腺， 剖検）
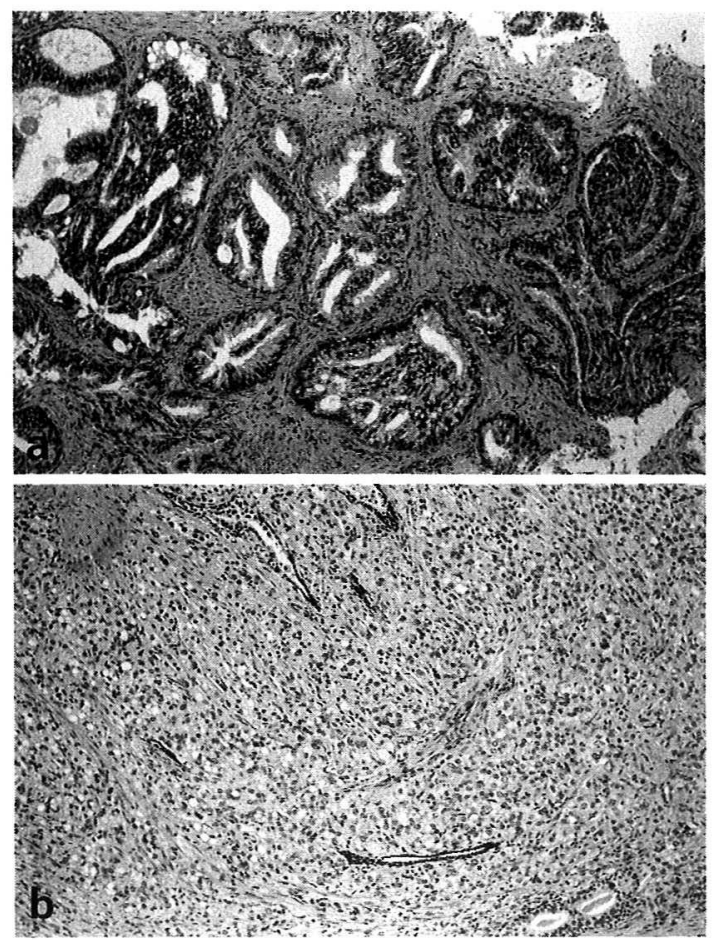

摘除術を施行した例は，全摘標本は，中分化型，剖検 では，前立腺欠損部を介して膀胱直腸瘦をなし，そこ に低分化型腺癌の浸潤があった。不変群は, 中分化型 21例のらち57\% (Fig. 2) 扝よび両者とも低分化型のも のであった (Table 2). Gleason score では, 変化群 は， $3+5$ であった 8 例のうち 6 例が $5+5$ となって 
Fig. 2. 症例 K.Y.

a. 中分化型（前立腺，生検)，b. 中分化型（前立腺, 剖検）
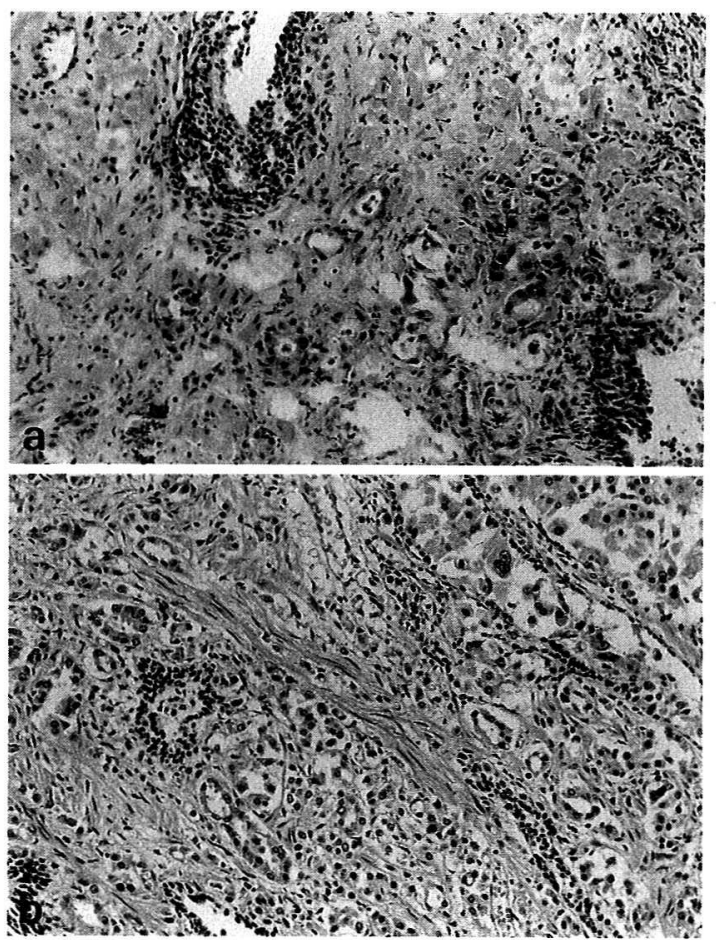

Table 2. 生検と剖検の比較

\begin{tabular}{|c|c|}
\hline 生検・剖検時 grade* & 例 数 \\
\hline 変 化 群 & $\begin{array}{c}9(24) \\
\text { (全例, 中分化型) }\end{array}$ \\
\hline 不 変 群 & $\begin{array}{c}28(76) \\
\left(\begin{array}{cc}\text { 中分化型 } & 12 \\
\text { 低分化型 } & 16\end{array}\right)\end{array}$ \\
\hline
\end{tabular}

* 前立腺癌取扱い規約

いた. $3+2$ のもの剖検時, $5+5$ と変化していた。 不変群は, $5+3$ が $5+5$ となったものが 6 例と最も 多く, 剖検時 score の大きくなったものは, $40 \%$ 占め ており，不変群として分類されていても，その内容は， 低分化傾向を示した。37例全体では，57\%のものが scoreが大となった（Table 3)。

2）初診時 stage：変化群は stage C 5 例，D 4 例, 不変群は，それぞれ10例および18例であり，不変群に stage Dの占める割合が大であった。

3）初診時年齡および観察期間：変化群の初診時年 齚は, $55 \sim 83$ 歳, 平均 68.0 歳, 不変群のそれは, 47〜83
Table 3. 生検・剖検間の Gleason score の变化

\begin{tabular}{|c|c|c|}
\hline \multirow{2}{*}{ 生検・剖検時 grade* } & Gleason score & \multirow{2}{*}{ 例数 } \\
\hline & 生検時 score 剖検時 score & \\
\hline \multirow{4}{*}{ 変化群（ 9例） } & $3+5 \longrightarrow 5+5$ & 6 \\
\hline & $3+5 \longrightarrow 5+3$ & 1 \\
\hline & $3+5 \longrightarrow 5+4$ & 1 \\
\hline & $3+2 \longrightarrow 5+5$ & 1 \\
\hline \multirow{10}{*}{ 不変群（28例） } & $3+5 \longrightarrow 3+5$ & 9 \\
\hline & $5+3 \longrightarrow 5+5$ & 6 \\
\hline & $5+3 \longrightarrow 5+3$ & 4 \\
\hline & $5+3 \longrightarrow 5+4$ & 2 \\
\hline & $3+3 \longrightarrow 3+5$ & 2 \\
\hline & $5+5 \longrightarrow 5+5$ & 1 \\
\hline & $\longrightarrow 5+4$ & 1 \\
\hline & $\longrightarrow 4+5$ & 1 \\
\hline & $\longrightarrow 5+5$ & 1 \\
\hline & $5+3 \longrightarrow 4+3$ & 1 \\
\hline
\end{tabular}

$*$ 前立腺癌取扱い規約

$\square$ ：剖検時, Gleason score が大となったもの

Table 4. 初診時血清酸性フォスファターゼ值

\begin{tabular}{c|c|c|c}
\hline \multirow{2}{*}{ 生検・剖検時 grade* } & \multicolumn{3}{|c}{ 酸性フォスファターゼ值 } \\
\cline { 2 - 4 } & 高 值 & 正常值 & 計 \\
\hline 変 化 群 & 8 & 1 & 9 \\
不 変 群 & 18 & 10 & 28 \\
\hline 計 & 26 & 11 & 37 \\
\hline
\end{tabular}

* 前立腺癌取扱い規約

歳, 平均69.4歳であり, 差をみなかった。

観察期間は, 前者が $2 \sim 102$ 力月, 平均 26.2 力, 後 者が 2 105力月, 平均31.0力月とこれも差をみなかっ た。

4）初診時酸性フォスファターゼ值：変化群は高值 を示したものが 8 例, 正常値のものが 1 例, 不変群は, それぞれ18例および10例であり，変化群に酸性フォス ファターゼ高值を示すものが多かった（Table 4).

5）治療内容：変化群は内分泌療法 7 例, 内分泌療 法十放射線療法 1 例扣よび下垂体照射 1 例であった。 不変群は14例が内分泌療法，13例が内分泌療法＋放射 線療法および 1 例が下垂体照射であり，内分泌療法十 放射線療法の占める割合が大であった（Table 5). 
6) 治療効果：内分泌療法有効例(再燃)は，変化群, 不変群両者に差をみなかった。変化群は不変群に比し， 局所再燃様式をとるものが多かった（Table 6)。

Table 5. 両群の治療内容

\begin{tabular}{|c|c|c|c|}
\hline \multirow{2}{*}{$\begin{array}{l}\text { 生検 - 剖検時 } \\
\text { grade* }\end{array}$} & 治 & 内 & 容 \\
\hline & 内分泌療法 & \begin{tabular}{|l} 
内分泌潦法 \\
放射線潦法併用
\end{tabular} & 下垂体照射 \\
\hline 変化群 & 7 & 1 & 1 \\
\hline 不変群 & 14 & 13 & 1 \\
\hline 計 & 21 & 14 & 2 \\
\hline
\end{tabular}

$*$ 前立腺癌取扱い規約

Table 6. 内分泌療法の効果

\begin{tabular}{|c|c|c|c|}
\hline \multirow{2}{*}{ 治療効 果 } & \multicolumn{2}{|c|}{ 生検・剖検時 grade } & \multirow{2}{*}{ 計 } \\
\hline & 変化群 & 不変群 & \\
\hline 無効 & 3 & (中1) 3 , 低 $\left.{ }^{2)} 7\right)$ & 13 \\
\hline 再燃3)（全身） & 1 & (中 4, 低 6 ) & 11 \\
\hline 再燃 (局所＋全身) 」有炑 & 4 & $\begin{array}{l}7 \\
\text { (中 } 4, \text { 低 } 3 \text { ) }\end{array}$ & 11 \\
\hline 計 & 8 & 27 & 35 \\
\hline
\end{tabular}

${ }^{*}$ 前立腺癌取扱い規約

${ }^{1)}$ 中分化型 ${ }^{2)}$ 低分化型 ${ }^{3)}$ 原発巣は臨床的に制癌状態 grade と内分泌療法の効果をみると, 中分化型は $68 \%$ ものが有効であった。低分化型は $56 \%$ の有効率 であり，前者より低かった（Table 7)。

7）転移部位：剖検時, 37 例全例に遠隔転移をみとめ た。リンパ節および骨が多く，ともに $95 \%$ に転移をみ た。変化群と不変群では，両者に差をみなかった (Table 8).

37 例のうち $65 \%$ は, 剖検時, 原発巣と転移巣に grade の差をみなかったが，残り $1 / 3$ は，両者の grade が異 なっていた。

原発巣が中分化型で転移巣が低分化型のものが10例 と大部分を占め(Fig. 3，4)，それぞれ低分化型拉よび 中分化型のものもあった (Table 9)。

\section{考按}

前立腺癌は $80 \%$ 以上の例が, 初回内分泌療法に反応 する ${ }^{8)}$. しかし数年のうちに過半数がホルモンに対す る反応性を失ない再燃する。な扔今回の検討では，対 象が剖検例のため内分泌療法無効例が $35 \%$ と多かっ た。前立腺癌の組織像は, 多様性で異なる grade の組 織が混在している。最近, grade とアンドロゲン結合蛋 白ないし前立腺癌組織中ジヒドロテストステロン (DHT) との関係が観察され, grade の低いものは, 両 者が少ないことが示された ${ }^{9111)}$ 。 またアンドロゲン結 合蛋白拈よびDHTは, 内分泌療法に対する反応性と

Table 7. grade 別の内分泌療法の効果

\begin{tabular}{|c|c|c|c|c|c|c|}
\hline \multirow{2}{*}{ 生検時 grade* } & \multirow{2}{*}{ 剖検時 grade* } & \multicolumn{3}{|c|}{ 内分泌療法の効果 } & \multirow[b]{2}{*}{\begin{tabular}{|l|} 
無効 \\
\end{tabular}} & \multirow{2}{*}{ 計 } \\
\hline & & 有効 $\rightarrow$ 再燃 & （全身， & 局所＋全身) & & \\
\hline 中1) & 低 ${ }^{2)}$ 変化群 & 5 & 1 & 4 & 3 & 8 \\
\hline 中 & 中) & 8 & 4 & 4 & 3 & 11 \\
\hline 低 & 低了不夌硨 & 9 & 6 & 3 & 7 & 16 \\
\hline
\end{tabular}

* 前立腺癌取扱い規約 $\quad$ 1) 中分化型 2 2) 低分化型

Table 8。剖検時遠隔転移部位

\begin{tabular}{|c|c|c|c|}
\hline 転移部位 & $\begin{array}{l}\text { 変化群 } \\
(9 \text { 例 })\end{array}$ & $\begin{array}{l}\text { 不変群 } \\
(28 \text { 例) }\end{array}$ & $\begin{array}{c}\text { 計 } \\
\text { (37例) }\end{array}$ \\
\hline リンパ節 & $7(78)$ & $28(100)$ & 35 (95) \\
\hline 骨 & $8(89)$ & $27(96)$ & 35 (95) \\
\hline 肺 & $4(44)$ & $17(61)$ & 21 (57) \\
\hline 肝 & 1 (11) & $13(46)$ & 14 (38) \\
\hline 副 & 1 (11) & $5(18)$ & $6(16)$ \\
\hline 腹膜。腸管 & 1 (11) & $2(7)$ & $3(8)$ \\
\hline 乳 & $0(0)$ & $1(4)$ & $1(3)$ \\
\hline
\end{tabular}

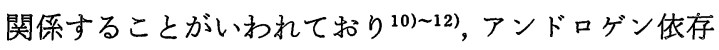
性の指標とみなされる。したがって grade とアンドロ ゲン依存性が関連することになり，今回の検討で当低， 分化型に内分泌㞠法無効例が多かった。以上のことよ り，低分化癌は高分化抒よび中分化癌より予後が悪い といえる13) 16)。

同一症例で grade の変化について検討した報告は 少なく，放射線療法前後の grade の変化をみた Kiesling の報告 ${ }^{17)}$, cryosurgeryによる組織学的変化を検 討したPetersonのそれ18)等を散見するのみである.前 
Fig. 3. C.Y.

a. 中分化型(前立腺, 剖検), b. 低分化型(リンパ節, 剖検）

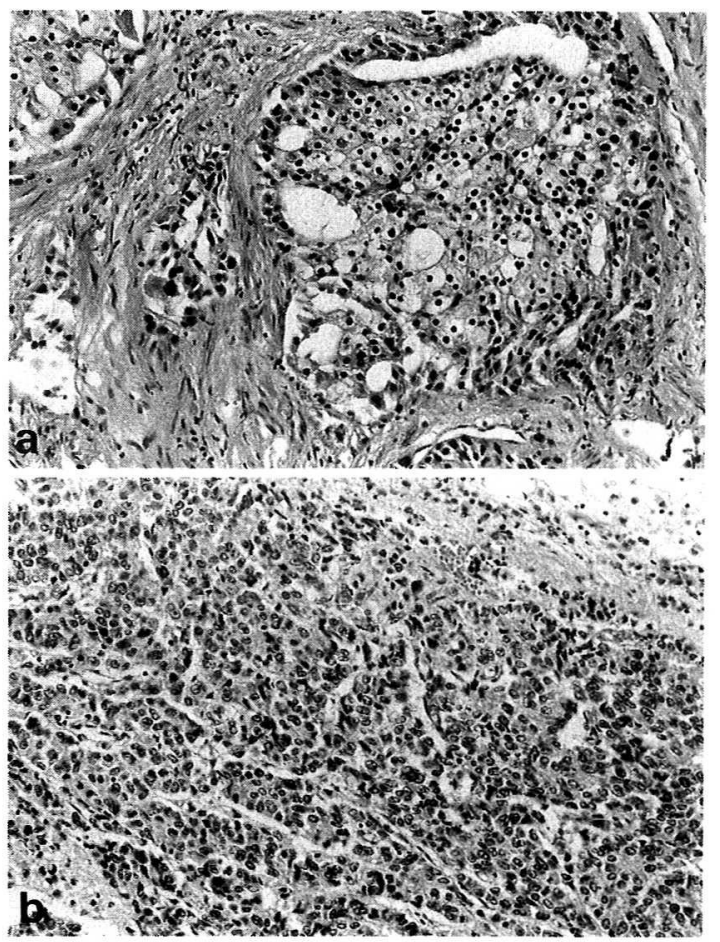

Table 9. 前立腺と遠隔転移部位の grade が異なる例

\begin{tabular}{|c|c|c|c|c|c|c|}
\hline \multirow{2}{*}{ 症例 } & \multirow{2}{*}{$\begin{array}{l}\text { 生検時, } \\
\text { 前立腺の } \\
\text { grade* }^{*}\end{array}$} & \multicolumn{5}{|c|}{ 剖検時, 前立腺および遠隔転移部位の grade* } \\
\hline & & 前立腺 & リンバ節 & 肝 & 肺 & 骨 \\
\hline 1 & 中1) & 中 & 低 ${ }^{2)}$ & & & \\
\hline 2 & 中 & 中 & 低 & & 低 & 中 \\
\hline 3 & 中 & 中 & 低 & 低 & 低 & \\
\hline 4 & 中 & 中 & 低 & 低 & & 低 \\
\hline 5 & 中 & 中 & & & & 低 \\
\hline 6 & 中 & 中 & 低 & 低 & 低 & 低 \\
\hline 7 & 中 & 低 & & & & 中 \\
\hline 8 & 中 & 中 & 低 & & & \\
\hline 9 & 中 & 中 & 低 & & 低 & 低 \\
\hline 10 & 中 & 中 & 低 & 低 & 低 & 低 \\
\hline 11 & 低 & 低 & 中 & & & 中 \\
\hline 12 & 中 & 中 & 低 & & & 低 \\
\hline 13 & 低 & 低 & 中 & & & 中 \\
\hline
\end{tabular}

$*$ 前立腺癌取扱い規約

1) 中分化型

2) 低分化型

立腺癌は経過が長く，剖検まで follow up できる症例 が少ないこと，治療後の生検が技術的に困難なことも 一因と思われる。

今回, 剖検時の原発巣の grade が生検時のそれに比
Fig. 4. 症例 R.T.

a. 中分化型 (前立腺，剖検)， b. 低分化型 (肝臓，剖 検)

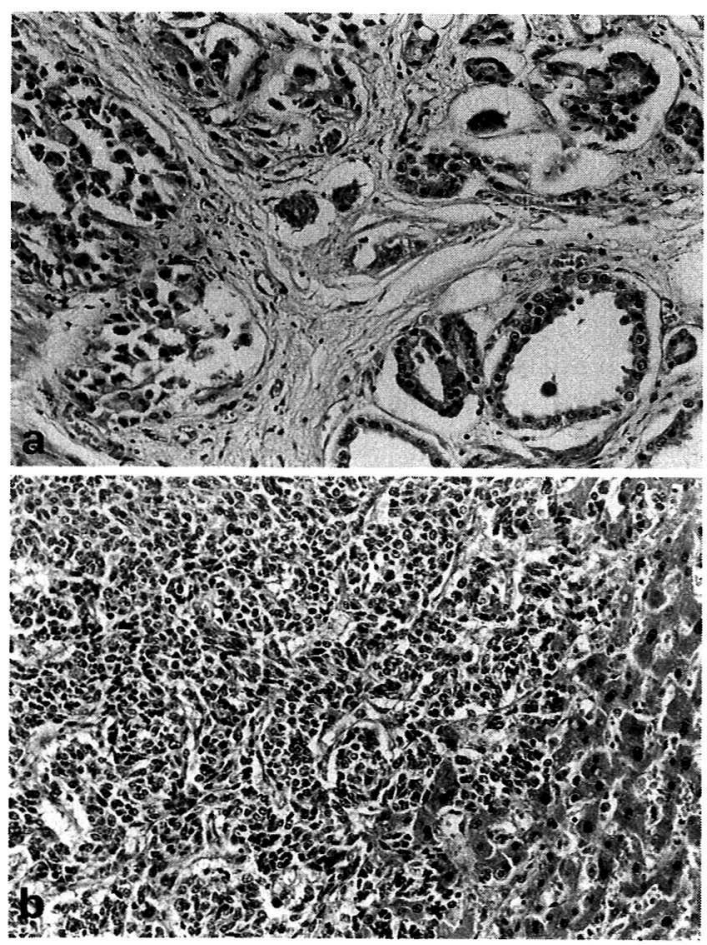

し，過半数の例で低分化傾向が示された。な和前回， 低分化癌が剖検時, 中分化型となった例を報告した $か^{3}$, さらに剖検時の全部位を検討した結果, 低分化癌 としたほらが良いとみなせたので，本報告では，それ に従った，異なる gradeよりなる前立腺癌は，依存性 の異なる組織の集合とみなしらるので, 内分泌療法施 行中に grade の高いアンドロゲン依存性のある組織 が脱落し，低分化の組織が残り，結局は，反応性のな いものの集団となることが考学られる。この点からみ ると低分化癌は内分泌療法抵抗性の可能性が大きい が，低分化癌でも内分泌療法開始時に反応し，早く再 燃することより，もし低分化癌の cell cycle が高分化 や中分化癌のそれより短かければ，早く性質が変化す ることも考㝋られる ${ }^{19)}$.

局所が臨床的に制癌されているものでも，剖検時, 癌組織の残存をみた。このことは, 内分泌療法により 低分化傾向になるが，再然するためには，なんらかの 機序で，これら残存した組織の性質が変化し増殖する ことを要するのだろう。自験例で中分化型から低分化 型に grade の変化したものに局所再燃例が多かった 
ことは，このことを示唆している。再燃例の進展が早 いことも，これを裏付けているものとい克る。ちなみ に内分泌療法後に再燃したものの組織のアンドロゲン 結合蛋白は，ほとんどみられないことも内分泌療法反 応性の消失をらかがわせる ${ }^{20)}$.

遠隔転移部位の組織像について, 原発巣のそれと比 較検討した報告は少ないが，悪性度の高い低分化の組 織が転移に関与寸るとの報告もある21). リンパ節に関 しては, staging pelvic lymphadenectomyによって光 られたリンパ節の grade は, 原発巣のそれと差がない とするものが多い22) 24). したがって今回, 剖検時, 転 移巣の grade は, 原発巣と同様, 低分化傾向を示した が，内分泌療法による影響と考えてよいだろう。

前立腺癌の進行に伴い, grade が変化し低分化傾向 を示すことを見い出した。したがって前立腺癌は， 1 つの治療法により制癌されたごとくみえても残存する 組織より再燃する可能性を示すものであり, 臨床的経 過をよく説明できる，以上をふまえて，前立腺癌の対 策に役立てたいと考えている。

\section{結 語}

前立腺癌剖検例37例について治療開始時の生検組織 像と剖検時のそれを比較検討した。

生検時, 中分化型21例(57\%), 低分化型16例(43\%) であったが，剖検時，前者は 9 例が低分化型となり， 12例は grade に変化なかった. 後者はいずれも grade は不変であった。37例中 25 例（68\%）が剖検時低分化 型となった。また，たとえ両者間に grade の差をみな くとも Gleason score でみると不変群28例中，40\%は 低分化傾向をみた。

低分化型で不変群に内分泌療法無効例が多かった。 剖検時, 転移部位の grade は, 13例 (34\%) は, 前 立腺と異なる grade を示したが，多くは，原発巣と同 じであった。

\section{文 献}

1) Huggins, C. and Hodges, C.V.: Studies on prostatic cancer. I. The effect of castration, of estrogen and of androgen injection on serum phosphatases in metastatic carcinoma of the prostate. Cancer Research, 1, 293-297, 1941.

2）島崎 淳, 宮内大成, 安藤 研, 桝鏡年清, 山口邦 雄, 角谷秀典, 岡野達弥, 小玉孝臣 : 前立腺癌の木 ルモン応答機構. 臨床科学, 19, 1312-1321, 1983.

3）安藤 研, 丸岡正幸, 桝鏡年清, 島崎 淳, 松㟢 理：前立腺癌剖検例の病理組織学的検討。日泌尿 会誌，74，989-993，1983。
4）島崎 淳, 伊藤晴夫, 宮内大成, 布施秀樹, 井坂茂 夫：前立腺癌の内分泌療法。Oncologia, 10，82 $-98,1984$.

5）布施秀樹, 安藤 研, 原繁, 座間秀一, 島崎 淳：前立腺癌の再燃と再燃癌に対する化学療法。 泌尿紀要，31，281-287，1985.

6) Gleason, D.F.: Classification of prostatic carcinomas. Cancer Chemother. Rep., 50, 125-128, 1966 。

7) 日本泌尿器科学会, 日本病理学会編：泌尿器。病 理。前立腺癌取扱い規約, 第 1 版. 金原出版, 東京。 1985 。

8）島崎 淳，伊藤晴夫，脇扳正美，丸岡正幸。宮内大 成, 野積邦義, 内藤 化, 松村 勉, 小玉孝臣：前 立腺癌とホルモン療法。臨床科学, 17, 877-885, 1981 。

9) Matsumura, T., Naito, H., Yamaguchi, K., Ito, H., Matsuzaki, O., Kambegawa, A. and Shimazaki, J.: Histochemical observation of R1881-binding protein in human prostatic cancer. Urol. Internat., 38, 25-28, 1983.

10) Geller, J., Vega, D.J. De La, Albert, J.D. and Nachtsheim, D.A.: Tissue dihydrotestosterone levels and clinical response to hormonal therapy in patients with advanced prostate cancer. J. Clin. Endocrinol. Metab., 58, 36-40, 1984.

11）武田克治：前立腺癌にょける androgen 依存性の biochemical indicator としての前立腺組織内 androgen 濃度に関する研究. 日泌尿会誌, 76, 1125-1137, 1985.

12) Yamaguchi, K., Sumiya, H., Fuse, H., Matsuzaki, O., Ito, H. and Shimazaki, J.: Androphilic protein studied histochemically in stage D2 prostatic cancer. Cancer, 61, 1425-1429, 1988 .

13) Gaeta, J.F., Asirwatham, J.E., Miller, G. and Murphy, G.P.: Histologic grading of primary prostatic cancer: A new approach to an old problem. J. Urol., 123, 689-693, 1980.

14) Wilson, D.E., Harper, M.E., Jensen, H.M., Ikeda, R.M., Richards, G., Peeling, W.B., Pierrepoint, C.G. and Griffiths, $\mathrm{K}$ : : A prognostic index for the clinical management of patients with advanced prostatic cancer: A British prostate study group investigation. The Prostate, 7 , 131-141, 1985.

15) Sogani, P.C., Israel, A., Lieberman, P.H., Lesser, M.L. and Whitmore, W.F. Jr.: Gleason grading of prostate cancer: A predictor of survival. Urology, 25, 223-227, 1985.

16）熊本悦明。塚本泰司, 島崎 淳, 大島博幸, 吉田 修, 斉藤 泰, 原田昌興：前立腺癌の予後因子の分 
析一前立腺癌の内分泌療法に抒ける検討一. 協栄 生命研究助成論文集 II, 21-33， 1986.

17) Kiesling, V.J., Mcaninch, J.M., Goebel, J.L. and Agee, R.E.: External beam radiotherapy for adenocarcinoma of the prostate: A clinical follow up. J. Urol., 124, 851-854, 1980.

18) Petersen, D.S., Milleman, L.A., Rose, E.F., Bonney, W.W., Schmidt, J.D., Hawtrey, C.E. and Culp, D.A.: Biopsy and clinical course after cryosurgery for prostatic cancer. J. Urol., 120, 308-311, 1978.

19) Lala, P.K.: Methods in cancer research, Edited by Harris Busch vol VI 4-95, Academic Press, New York, and London, 1971.

20）角谷秀典, 石井弘之, 布施秀樹, 松笴 理, 島崎 淳：前立腺癌アンドロゲン結合蛋白の組織化学： Gleason 分類および再燃例について. 第75回日本 泌尿器科学会総会, 1987.
21) Heaney, J.A., Chang, H.C., Daly, J.J. and Prout, G.R. Jr.: Prognosis of clinically undiagnosed prostatic carcinoma and the influence of endocrine therapy. J. Urol., 118, 283-287, 1977.

22) Kodama, T., Gotohda, E., Takeichi, N., Kuzumaki, N. and Kobayashi, H.: Histopathology of regression of tumor metastasis in the lymph nodes. Cancer Res., 35, 1628-1636, 1975.

23) Murphy, P., Gaeta, J.F., Pickren, J. and Wajsman, Z.: Current status of classification and staging of prostate cancer. Cancer, 45, 1889 $-1895,1980$.

24）布施秀樹, 座間秀一, 秋元 晋, 島崎 淳, 松㟢 理, 村上信乃, 五十嵐辰男：前立腺癌の staging pelvic lymphadenectomy. 泌尿紀要, 32, 1465 $-1470,1986$.

（1988年 3 月 1 日受理） 